\title{
Blood pressure and five year survival in the very old
}

\author{
KARI MATTILA, MATTI HAAVISTO, SULO RAJALA, RAUNO HEIKINHEIMO
}

\begin{abstract}
During $1977-8$ we measured blood pressure in 561 old people ( $83 \%$ of those aged 85 or more living in Tampere) and analysed their five year survival according to their blood pressure group. The subjects were divided into six groups on the basis of their blood pressures (from $<120$ to $>200 \mathrm{~mm} \mathrm{Hg}$ systolic, from $<70$ to $>110$ diastolic). The greatest mortality was observed in those in the lowest systolic and lowest diastolic groups. Mortality was least in subjects with systolic pressures of $160 \mathrm{~mm} \mathrm{Hg}$ or more and diastolic pressures of $90 \mathrm{~mm} \mathrm{Hg}$ or more.

The most essential finding in this series of the very old was an increased mortality in the lowest blood pressure groups.
\end{abstract}

\section{Introduction}

On World Health Organisation criteria blood pressure is considered to be increased when the systolic pressure is over $160 \mathrm{~mm} \mathrm{Hg}$ and the diastolic pressure over $95 \mathrm{~mm} \mathrm{Hg} .{ }^{12}$ These levels may mark the point at which medical treatment for high blood pressure should be called for in the elderly. ${ }^{3}$

We were surprised to observe an inverse relation between both systolic and diastolic blood pressures and the two year mortality in people aged 85 years and older. ${ }^{4}$ We then discovered that others had previously found that high blood pressure did not seem to increase the risk of death in the elderly. ${ }^{5.9}$ Our observation also provoked discussion about its possible causes and practical importance. ${ }^{10-12}$

The purpose of the five year follow up study reported here was to confirm the observation and further analyse this phenomenon.

Department of Public Health, University of Tampere, Finland

KARI MATTILA, MD, acting professor of gerontology

Department of Geriatric Medicine, Tampere City Hospital, SF-33500 Tampere, Finland

MATTI HAAVISTO, $\mathrm{MD}$, assistant chief physician

SULO RAJALA, MD, senior registrar

RAUNO HEIKINHEIMO, MD, chief physician

Correspondence to: Dr Heikinheimo.

\section{Study population and methods}

The target group in this study consisted of 674 people born in 1892 or earlier and living in the city of Tampere in 1977. Out of the total cohort 561 people $(83 \%)$ participated in the initial examination in $1977-8 .{ }^{13}$ Their mean age (standard deviation) was $88.4(2 \cdot 8)$ years, and $462(82 \%)$ were women (fig 1). More than half the subjects (272) were living at home, 162 in old people's homes, and 123 in hospital (4 not classified).

Blood pressures were measured by a physician $(\mathrm{MH})$, after rest with the subject sitting, by a mercury manometer with the cuff on the right arm. The blood pressure of bedridden patients was measured in recumbent position. The level of diastolic blood pressure was recorded at the fourth phase of Korotkoff's sounds. ${ }^{14}$ The subjects were divided into six groups according to their level of systolic and diastolic blood pressure. The limits of systolic blood pressure were $120,140,160,180$, and $200 \mathrm{~mm} \mathrm{Hg}$ and those of diastolic pressure 70, 80, 90, 100, and $110 \mathrm{~mm} \mathrm{Hg}$.

The criterion for arterial hypertension was hypertensive disease diagnosed and treated by a physician or a diastolic blood pressure of $110 \mathrm{~mm} \mathrm{Hg}$ or over in repeated measurements. The number of hypertensive subjects was 37 $(6 \cdot 6 \%)$. Only one new hypertensive patient was discovered.

The survival of the cohort was followed until 31 December 1982. Four of the 561 subjects were lost to follow up. The survival rates and the relative survival rates were estimated using a method which takes into account the error caused by the heterogeneity in age and sex of the subjects to be followed up. ${ }^{15}$ The Finnish population aged 85 years or over (1976-80) was used as a normal population. With this method, if the survival of the group examined corresponds to that in the normal population of the same sex and age distribution the relative survival rate is 1 . Values over 1 represent lower mortality and values less than 1 higher mortality, and the more the value deviates from 1 the greater is the divergence from average.

The significance of differences between blood pressure groups was investigated by Student's $t$ test. The statistical significance of the difference between the two curves made up of relative survival rates was tested by a likelihood ratio test. ${ }^{16}$

\section{Results}

Blood pressure averaged 144/83 (18/11) $\mathrm{mm} \mathrm{Hg}$ among men and 154/84 $(25 / 13) \mathrm{mm} \mathrm{Hg}$ among women (systolic difference: $t=3 \cdot 77, \mathrm{df}=558$, $\mathrm{p}<0.001$; diastolic difference: $t=0.71, \mathrm{df}=558, \mathrm{p}>0.05$ ).

Those with low systolic and diastolic blood pressures were leaner and their average blood glucose and serum cholesterol concentrations and packed cell volumes were lower (table I). The proportion of hospital inpatients was greatest in the lowest blood pressure groups and that of subjects at home was greatest in the high blood pressure groups (tables II and III). The prevalence of dementia was higher in the lowest systolic and diastolic groups than in the 
other groups (tables II and III). The proportion of people with hypertensive disease was, of course, greatest in the highest blood pressure groups.

TABLE I-Correlations of age, body mass index, blood glucose and serum cholesterol concentrations, and packed cell volume with systolic and diastolic blood pressure

\begin{tabular}{|c|c|c|c|}
\hline & \multirow[b]{2}{*}{$\begin{array}{c}\operatorname{Mean}(\mathrm{SD}) \\
(\mathrm{n}=561)\end{array}$} & \multicolumn{2}{|c|}{ Blood pressure } \\
\hline & & $\begin{array}{c}\text { Systolic } \\
\mathrm{r}\end{array}$ & $\begin{array}{c}\text { Diastolic } \\
\mathrm{r}\end{array}$ \\
\hline Age (years) & $88 \cdot 4(2 \cdot 8)$ & $-0 \cdot 17$ & $-0 \cdot 21$ \\
\hline Body mass index $\left(\mathrm{kg} / \mathrm{m}^{2}\right)$ & $23 \cdot 4(4 \cdot 2)$ & $0 \cdot 27$ & $0 \cdot 31$ \\
\hline Fasting blood glucose $(\mathrm{mmol} / \mathrm{l})$ & $5 \cdot 1(1 \cdot 5)$ & $0 \cdot 15$ & $0 \cdot 14$ \\
\hline Serum cholesterol $(\mathrm{mmol} / \mathrm{l})$ & $6 \cdot 3(1 \cdot 4)$ & $0 \cdot 15$ & $0 \cdot 17$ \\
\hline Packed cell volume (\%) & $41 \quad(4 \cdot 3)$ & $0 \cdot 17$ & $0 \cdot 26$ \\
\hline
\end{tabular}

$\mathrm{p}<0 \cdot 001$ when $\mathrm{r}=0 \cdot 14$.
The increased survival of subjects in the highest blood pressure groups was clear (table IV). The trend did not depend on place of residence. The mortality was highest in the lowest systolic (fig 2) and in the lowest diastolic (fig 3) blood pressure groups. The mortality was lowest in the groups with systolic pressures of $160 \mathrm{~mm} \mathrm{Hg}$ and over and with diastolic pressures of $90 \mathrm{~mm} \mathrm{Hg}$ and over. The relative survival curve of subjects in the lowest systolic blood pressure group was significantly different from the "normal" $140-159 \mathrm{~mm} \mathrm{Hg}$ group curve $\left(\chi^{2}=18.9, \mathrm{df}=5, \mathrm{p}<0.001\right)$. The relative survival curve of the lowest diastolic blood pressure group was significantly different from the "normal" $80-89 \mathrm{~mm} \mathrm{Hg}$ curve $\left(\chi^{2}=23 \cdot 3, \mathrm{df}=5\right.$, $\mathrm{p}<0.001)$. The difference between the highest systolic curve $(>200 \mathrm{~mm} \mathrm{Hg})$ and the "normal" $140-159 \mathrm{~mm} \mathrm{Hg}$ curve was also significant $\left(\chi^{2}=10.9\right.$, $\mathrm{df}=4, \mathrm{p}<0.05)$, whereas the difference between the highest diastolic curve $(>110 \mathrm{~mm} \mathrm{Hg})$ and the "normal" $80-89 \mathrm{~mm} \mathrm{Hg}$ curve was not $\left(\chi^{2}=5 \cdot 2\right.$, $\mathrm{df}=5, \mathrm{p}>0.05)$.

The five year survival rate of patients with hypertensive disease $(59 \%)$ was higher than that of others $(28 \%)$. The average blood pressures of patients

TABLE II-Place of treatment, diseases, and sex of the examined persons in systolic blood pressure groups. Results are numbers (and percentages)

\begin{tabular}{|c|c|c|c|c|c|c|}
\hline & \multicolumn{6}{|c|}{ Systolic blood pressure (mm $\mathrm{Hg})$} \\
\hline & $\begin{array}{c}<120 \\
(\mathrm{n}=38)\end{array}$ & $\begin{array}{c}120-139 \\
(n=91)\end{array}$ & $\begin{array}{c}140-159 \\
(n=178)\end{array}$ & $\begin{array}{l}160-179 \\
(n=163)\end{array}$ & $\begin{array}{c}180-199 \\
(n=67)\end{array}$ & $\begin{array}{c}>200 \\
(\mathrm{n}=20)\end{array}$ \\
\hline \multicolumn{7}{|l|}{ Place of treatment: } \\
\hline Home & $7(18)$ & $25(27)$ & $87(49)$ & $95(59)$ & $43(64)$ & $15(75)$ \\
\hline Old people's home & $12(32)$ & $27(31)$ & $54(30)$ & $49(30)$ & $17(25)$ & $3(15)$ \\
\hline Hospital & $19(50)$ & $39(43)$ & $37(21)$ & $19(12)$ & $7(10)$ & $2(10)$ \\
\hline \multicolumn{7}{|l|}{ Diseases: } \\
\hline Dementia, confusion & $26(68)$ & $39(43)$ & $53(30)$ & $35(21)$ & $14(21)$ & $4(20)$ \\
\hline Heart failure & $18(47)$ & $51(56)$ & $84(47)$ & $77(47)$ & $34(51)$ & $10(50)$ \\
\hline Coronary heart disease & $4(11)$ & $17(19)$ & $27(15)$ & $25(15)$ & $10(15)$ & $3(15)$ \\
\hline Atrial fibrillation & $9(24)$ & $18(20)$ & $28(16)$ & $28(17)$ & $11(16)$ & $3(15)$ \\
\hline Hypertensive disease & 0 & $2(2)$ & $5(3)$ & $15(9)$ & $10(15)$ & $5(25)$ \\
\hline Diabetes & $1(3)$ & $15(17)$ & $36(20)$ & $28(17)$ & $11(17)$ & $4(20)$ \\
\hline Urinary tract infection & $12(32)$ & $20(22)$ & $36(20)$ & $33(20)$ & $15(22)$ & $6(30)$ \\
\hline \multicolumn{7}{|l|}{ Sex: } \\
\hline Men & $7(18)$ & $21(23)$ & $45(25)$ & $22(13)$ & $4(6)$ & 0 \\
\hline
\end{tabular}

TABLE III-Place of treatment, diseases, and sex of the people examined according to diastolic blood pressure groups. Results are numbers (and percentages)

\begin{tabular}{|c|c|c|c|c|c|c|}
\hline & \multicolumn{6}{|c|}{ Diastolic blood pressure $(\mathrm{mm} \mathrm{Hg})$} \\
\hline & $\begin{array}{c}<70 \\
(\mathrm{n}=47)\end{array}$ & $\begin{array}{c}70-79 \\
(\mathrm{n}=89)\end{array}$ & $\begin{array}{c}80-89 \\
(n=185)\end{array}$ & $\begin{array}{c}90-99 \\
(n=154)\end{array}$ & $\begin{array}{c}100-109 \\
(n=59)\end{array}$ & $\begin{array}{c}>110 \\
(n=23)\end{array}$ \\
\hline \multicolumn{7}{|l|}{ Place of treatment: } \\
\hline Home & $10(21)$ & $30(33)$ & $95(51)$ & $86(55)$ & $34(59)$ & $17(74)$ \\
\hline Old people's home & $9(19)$ & $28(31)$ & $57(31)$ & $47(31)$ & $17(28)$ & $4(17)$ \\
\hline Hospital & $28(60)$ & $31(35)$ & $33(18)$ & $21(14)$ & $8(14)$ & $2(9)$ \\
\hline \multicolumn{7}{|l|}{ Diseases: } \\
\hline Dementia, confusion & $28(60)$ & $30(33)$ & $59(32)$ & $39(25)$ & $13(22)$ & $4(17)$ \\
\hline Heart failure & $24(52)$ & $47(53)$ & $104(56)$ & $66(43)$ & $28(47)$ & $6(26)$ \\
\hline Coronary heart disease & $11(23)$ & $15(17)$ & $28(15)$ & $28(18)$ & $4(7)$ & $3(13)$ \\
\hline Atrial fibrillation & $8(17)$ & $12(13)$ & $41(22)$ & $20(13)$ & $15(25)$ & $1(4)$ \\
\hline Hypertensive disease & 0 & 0 & $6(3)$ & $12(8)$ & $10(17)$ & $8(35)$ \\
\hline Diabetes & $4(8)$ & $13(14)$ & $30(16)$ & $34(22)$ & $12(21)$ & $5(22)$ \\
\hline Urinary tract infection & $14(30)$ & $17(19)$ & $33(18)$ & $35(23)$ & $13(22)$ & $10(43)$ \\
\hline \multicolumn{7}{|l|}{ Sex: } \\
\hline Men & $7(15)$ & $19(21)$ & $39(21)$ & $22(14)$ & $11(18)$ & $1(4)$ \\
\hline
\end{tabular}

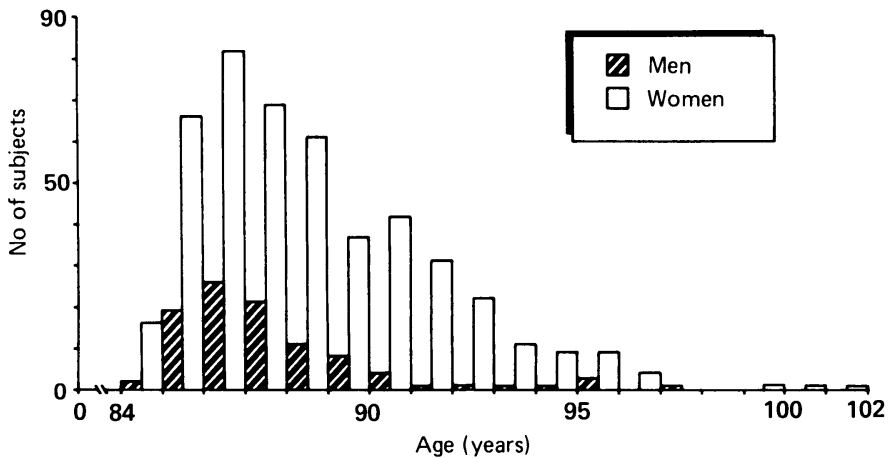

FIG 1-Age and sex distribution of subjects in initial health survey. with arterial hypertension were also higher $(173 / 97(24 / 12) \mathrm{mm} \mathrm{Hg})$ than those of the rest of the subjects $(151 / 83(24 / 12)) \mathrm{mm} \mathrm{Hg}$ (systolic difference: $t=5 \cdot 43, \mathrm{df}=558, \mathrm{p}<0 \cdot 001$; diastolic difference: $t=6 \cdot 89, \mathrm{df}=558, \mathrm{p}<0 \cdot 001$ ).

\section{Discussion}

The people examined were very old and thus, as shown by their long lives, genetically selected. ${ }^{12}$ As we aimed to include all the inhabitants of Tampere aged over 85 our study also included the frailest old people. The cohort was strongly dominated by women. The methods we used corrected the bias of survival comparison caused by this predominance of women and by the age difference between the sexes in the cohort.

Ill health has been suggested to cause both a fall in blood pressure 
and an increase in mortality. ${ }^{10}{ }^{17}$ The inverse association between blood pressure and mortality in our series was not, however, related to the health of these elderly people as shown by their place of residence.

TABLE IV-Five year survival (SD) in systolic and diastolic blood pressure groups according to place of residence. Institutional care means living at hospital or old people's home

\begin{tabular}{|c|c|c|c|c|c|c|}
\hline \multirow[b]{2}{*}{$\begin{array}{l}\text { Blood pressure } \\
(\mathrm{mm} \mathrm{Hg})\end{array}$} & \multicolumn{2}{|c|}{ At home } & \multicolumn{2}{|c|}{ In institutional care } & \multicolumn{2}{|r|}{ Total } \\
\hline & No & $\begin{array}{c}\text { Five year } \\
\text { survival (SD) } \\
(\%)\end{array}$ & No & $\begin{array}{c}\text { Five year } \\
\text { survival (SD) } \\
(\%)\end{array}$ & No & $\begin{array}{c}\text { Five year } \\
\text { survival }(\mathrm{SD}) \\
(\%)\end{array}$ \\
\hline \multicolumn{7}{|l|}{ Systolic: } \\
\hline$<120$ & 7 & $14(13)$ & 31 & $3(3)$ & 38 & $5(4)$ \\
\hline $120-139$ & 25 & $24(9)$ & 66 & $10(4)$ & 91 & $14(4)$ \\
\hline $140-159$ & 87 & $43(5)$ & 91 & $15(4)$ & 178 & $29(4)$ \\
\hline $160-179$ & 95 & 49 (5) & 68 & $28(6)$ & 163 & 40 (4) \\
\hline $180-199$ & 43 & $50(8)$ & 24 & $17(8)$ & 67 & $39(6)$ \\
\hline$>200$ & 15 & $40(13)$ & 5 & $60(22)$ & 20 & $44(12)$ \\
\hline \multicolumn{7}{|l|}{ Diastolic: } \\
\hline$<70$ & 10 & $20(13)$ & 37 & $4(3)$ & 47 & $8(4)$ \\
\hline $70-79$ & 30 & $39(9)$ & 59 & $8(4)$ & 89 & $19(4)$ \\
\hline $80-89$ & 95 & 42 (5) & 90 & $18(4)$ & 185 & $31 \quad(3)$ \\
\hline $90-99$ & 86 & $48(5)$ & 68 & $26(6)$ & 154 & $39(4)$ \\
\hline $100-109$ & 34 & $45 \quad(9)$ & 25 & $20(9)$ & 59 & $35(7)$ \\
\hline$>110$ & 17 & $47(12)$ & 6 & $40(24)$ & 23 & $46(11)$ \\
\hline
\end{tabular}

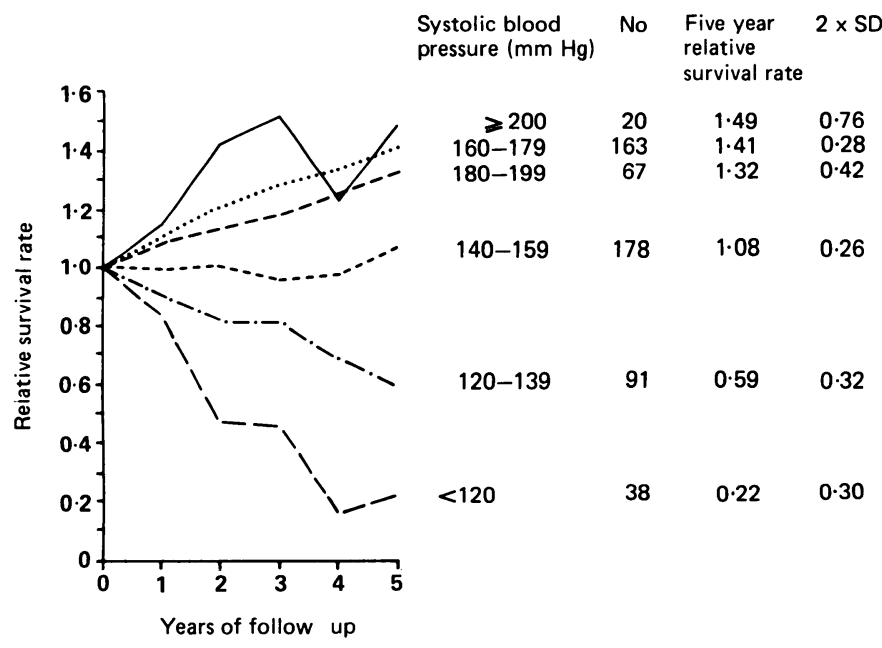

FIG 2 -Relative survival curves and 5 year relative survival rates $(2 \times \mathrm{Sl})$ of subjects in systolic blood pressure groups.

Raised blood pressure has usually been regarded as increasing the risk of mortality in the elderly. ${ }^{18} 19$ Our results lend support to observations that high blood pressure is not associated with an excess risk of mortality. ${ }^{5.9}$ In fact, our findings suggest that as blood pressure is raised in the very old the risk of death is no longer increased but diminished. Those people with hypertensive disease had higher blood pressures and a better survival prognosis than the

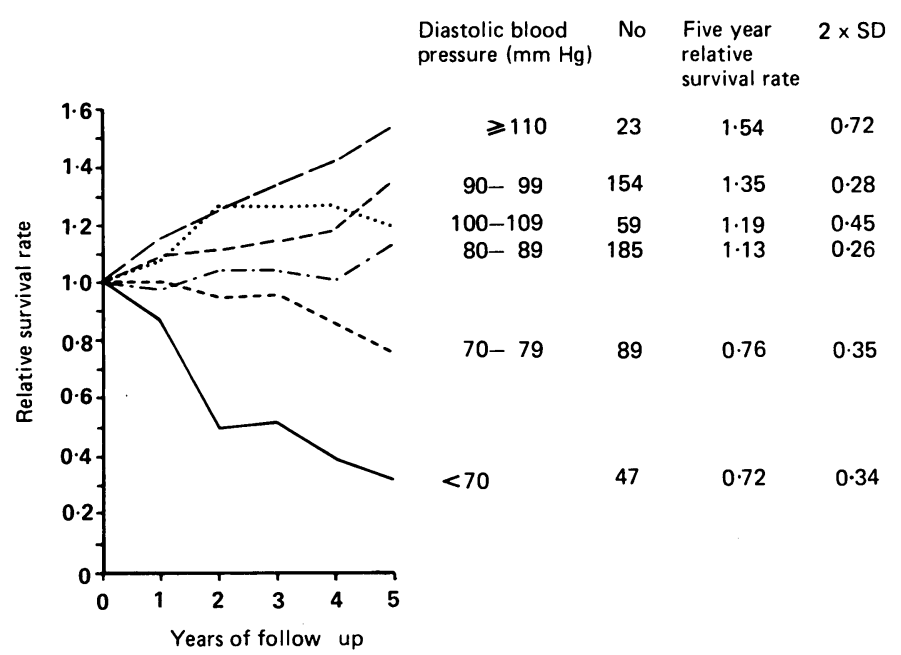

FIG 3-The relative survival curves and 5 year relative survival rates (and $2 \times \mathrm{SD}$ ) of subjects in diastolic blood pressure groups.

others. A moderately high blood pressure would seem to indicate an adequately functioning cardiovascular system.

It is now essential to ascertain-whether raised blood pressure ceases to be a risk factor in the very old. The criteria for treating high blood pressure in the elderly and the target levels for treatment should thereafter be reviewed, at least in the very old.

This study was supported by the Yrjö Jahnsson Foundation, Finland.

\section{References}

1 World Health Organisation. Hypertension and coronary heart disease: Classification and criteria for epidemiological studies. Geneva: WHO, 1959. (Technical Report Series 168.)

World Health Organisation. Arterial hypertension and ischaemic heart disease. Preventive aspects. Geneva: WHO, 1962. (Technical Report Series 231.)

3 Franklin SS. Geriatric hypertension. Med Clin North Am 1983;67:395-417.

4 Rajala S, Haavisto M, Heikinheimo R, Mattila K. Blood pressure and mortality in the very old. Lancet 1983;ii:520-1.

5 Sourander L, Ruikka I, Kasanen A. A health survey on the aged with 5-year follow-up. Acta Soc Med Scand 1970;suppl 3:1-41.

6 Fry J. Natural history of hypertension: a case for selective non-treatment. Lancet 1974;ii:431-3.

7 Andersson F, Cowan NR. Survival of healthy older people. Br f Prev Soc Med 1976;30:231-2.

8 Sprackling ME, Mitchell JRA, Short AH, Watt G. Blood pressure reduction in the elderly: a randomized controlled trial of methyldopa. Br Med f 1981;283:1151-3.

9 Lindholm L, Schersten B, Thulin T. Hypertension in elderly people in a Swedish primary care district. Scand F Prim Health Care 1983;3-4:120-31.

10 MacLennan WJ. High blood pressure and mortality in the elderly. Lancet 1983;ii:746

11 Coope JR. High blood pressure and mortality in the elderly. Lancet 1983;ii:746.

12 Burch PRJ. Blood pressure and mortality in the very old. Lancet 1983;ii:852-3.

13 Haavisto M, Geiger U, Mattila K, Rajala S. A health survey of the very aged in Tampere, Finland. Age Ageing 1984;13:266-72.

14 Rose GA, Blackburn H. Cardiovascular survey methods. Geneva: WHO, 1968.

15 Hakulinen T. Cancer survival corrected for heterogeneity in patient withdrawal. Biometrics 1982;38:933-42.

16 Hakulinen T, Abeywickrama $\mathrm{KH}$. A computer program package for relative survival analysis. Comput Programs Biomed 1985;19:197-207.

17 Hulme A, Murdoch C, Ritchie RT, Ghosh UK, MacLennan WJ. Low blood pressures in old women receiving long term care. $\mathcal{F}$ Clin Exp Gerontol 1981;3:353-65.

18 Holme I, Waaler HT. Five-year mortality in the city of Bergen, Norway, according to age, sex and blood pressure. Acta Med Scand 1976;200:229-39.

19 Aromaa A. Epidemiology and public health impact of high blood pressure in Finland. Helsinki: Social Insurance Institution, 1981.

(Accepted 30 November 1987) 